\title{
RECENT BALD EAGLE BREEDING RANGE EXPANSION IN MANITOBA
}

RUDOLF KOES, 135 Rossmere Crescent, Winnipeg, MB, R2K 0G1; E-mail: <rkoes@ mts.net>

Since discovering a Bald Eagle nest near Oak Hammock Marsh Wildlife Management Area, southern Manitoba, in the late 1990s, I have kept an informal log of "out-of-range" Bald Eagle nests that I found or heard of in subsequent years. It soon became clear that increasing numbers of Bald Eagles were starting to nest outside of their traditional boreal forest range, in agricultural areas where they had not been known to breed as recently as just a few decades ago. In this paper, I attempt to delineate the current (as of 2009) Bald Eagle breeding range in Manitoba south and west of the continuously forested regions of the province (i.e. in "agricultural" Manitoba), with a brief note about breeding range expansion to the north.

\section{Data Collection}

To get a more complete picture of bald eagle nest distribution, in spring 2009 a query was posted on the Yahoo group manitobabirds, which resulted in numerous responses; in addition, many observers were contacted personally. Discussions and e-mails between myself and $C$. Cuthbert (Ducks Unlimited Canada), K. De Smet (Manitoba Conservation), W. Koonz (formerly of Manitoba Natural Resources), and P. Taylor (Nature Manitoba) were particularly productive in producing records and providing leads. After eliminating duplicate records, a list of over 50 nest sites within the nonforested parts of southern Manitoba was produced. In addition, results from aerial Bald Eagle surveys conducted in the 1980 s by Manitoba Natural Resources personnel were studied to establish the nesting range during that time. The numerous (hundreds) nests mapped during these surveys were almost all located outside of the area of southern Manitoba discussed in this paper, but they give a good indication of the extent of the breeding range about 25 years ago.

\section{History}

The status of the Bald Eagle as a breeding bird in Manitoba was apparently not well known in the $19^{\text {th }}$ century. Ernest Thompson Seton's correspondents variously described it as "very rare summer visitant, probably breeding..... several nests noted [along the Red River]; summer resident, tolerably common; rare; common between latitude $62^{\circ}$ and Lake Superior" [brackets and punctuation mine]. ${ }^{8}$ What is clear is that the species nested away from the boreal forest, along the Red River - and probably elsewhere along treed river courses - in the mid- and late 1800 s. There is very little information about breeding status in the first half of the $20^{\text {th }}$ century, but by mid-century, the species was absent as a breeder in southern Manitoba. Other than one or two anecdotal reports of nests in the late 1980s, none of the over 40 long-term birders I have contacted recall nests in agricultural areas of Manitoba before the 1990s. The aerial surveys mentioned above took place from 1982 to 1987 and were particularly focused on the Lake Winnipegosis area. These surveys also showed that the breeding range did not include any of the areas identified as agricultural Manitoba during the mid1980s (Fig. 1). 


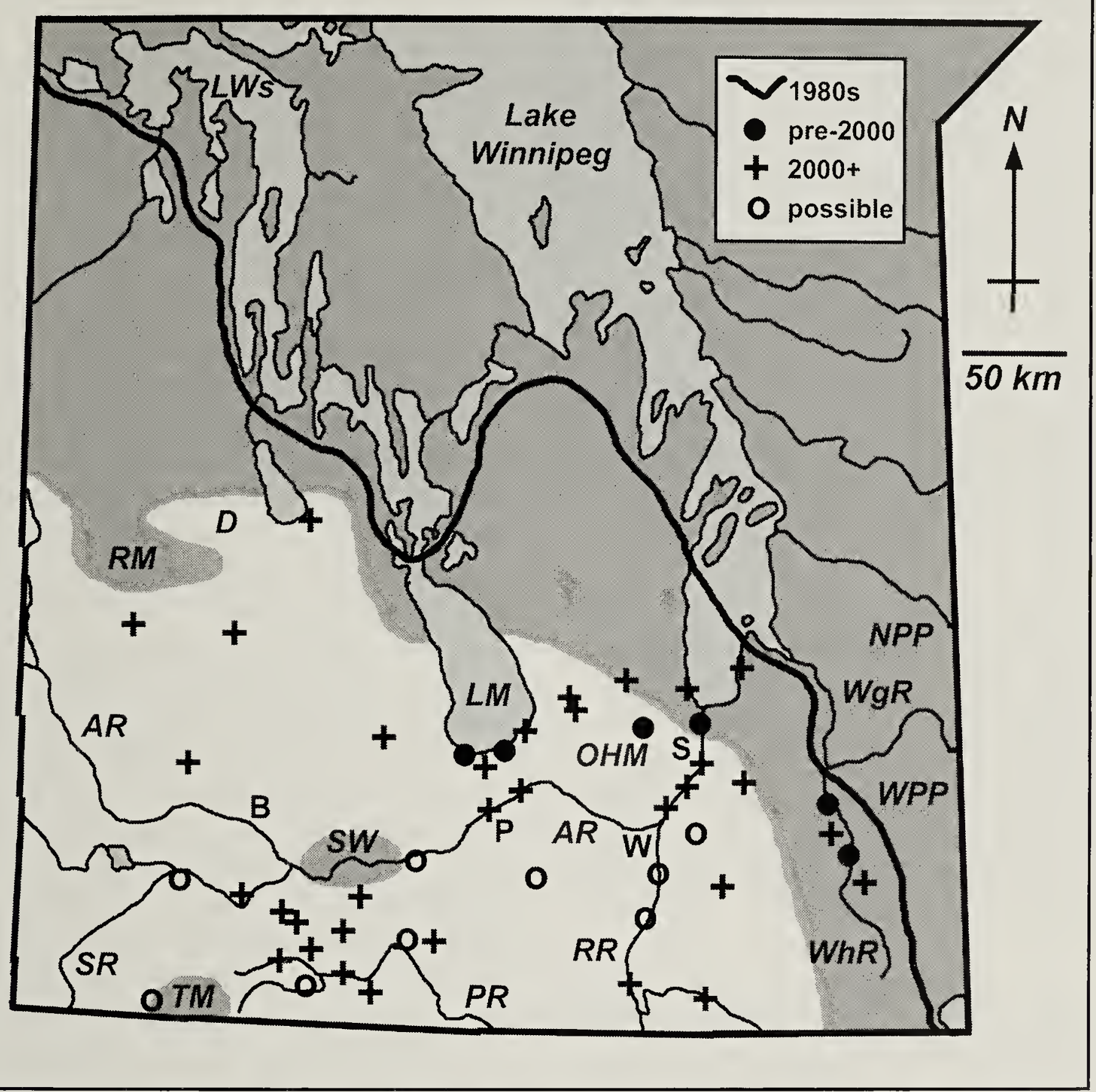

Figure 1. Locations of Bald Eagle nests in agricultural southern Manitoba. AR - Assiniboine River, B - Brandon, D - Dauphin, LM - Lake Manitoba, LWs - Lake Winnipegosis, NPP - Nopiming Provincial Park, OHM - Oak Hammock Marsh, $P$ - Portage la Prairie, PR - Pembina River, RM - Riding Mountain, RR - Red River, S - Selkirk, SR - Souris River, SW - Spruce Woods, TM - Turtle Mountains, W - Winnipeg, WgR - Winnipeg River, WhR - Whitemouth River, WPP - Whiteshell Provincial Park

It appears that the overall decline of Bald Eagle numbers across North America during the early and mid-20 $20^{\text {th }}$ century also caused a contraction of the Manitoba breeding range, so that nesting was essentially restricted to the boreal forest and along the shores of Manitoba's "Great Lakes" at that time. Even the map in the Bald Eagle account in The Birds of Manitoba, published as recently as 2003 , shows the breeding range restricted to the areas noted above, although mention is made in the text that "the species is currently extending its breeding range into agricultural regions across southern Manitoba."”

\section{Nests and Nest Trees}

While Bald Eagles may nest on "rocky cliffs or on pinnacles of rock" in areas 


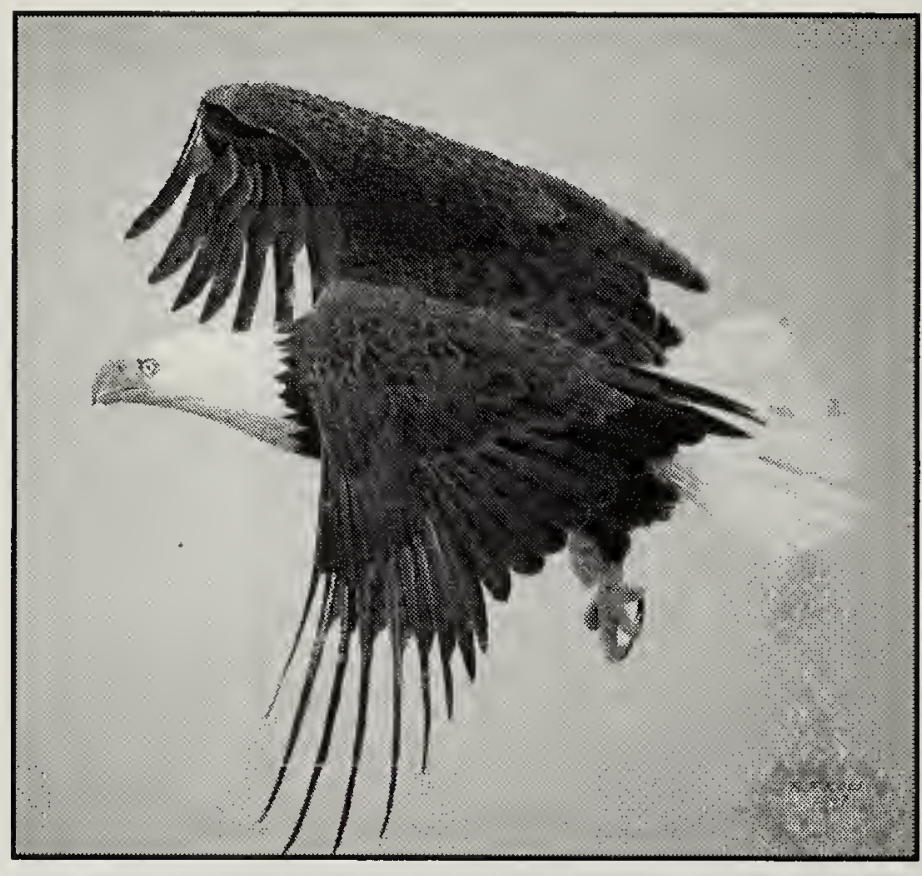

Bald Eagle. Original artwork by Rudolf Koes.

where no trees exist and in a variety of tree species elsewhere, they typically use large conifers when nesting in Canada's boreal forest. ${ }^{1,3}$ Koonz stated that "nest trees in the south are often deciduous with conifers more often chosen northward". He also noted that over $90 \%$ of the nests in deciduous trees were in Populus (spp.) trees. ${ }^{6}$

During the compilation of nest records for this study, correspondents were asked to indicate the species of nest tree, if known. For 20 of the $50+$ nests, 13 were in aspen and seven in cottonwoods. Nests along riverbanks and the shores of large lakes were in cottonwoods, while nests away from water were always in aspen bluffs. Both live and dead trees were used. Live trees dominated, and were likely chosen because they remain standing longer than dead trees and their foliage may provide shade for the nest and young. However, aspen are relatively short-lived trees, and many nests made in them did not last more than a few years before the nest collapsed or the tree fell down. In most cases, new nests were built in the immediate vicinity of the old nests. For example, at Oak Hammock Marsh, the eagles currently (in 2009) occupy a nest about $100 \mathrm{~m}$ west of the location of their first nest. Nests in cottonwoods seem to last longer, and these account for most of the earliest nests noted in this paper, such as those along the Red River and the Whitemouth River. No attempt has been made to record nest heights or productivity.

\section{Range Expansion}

It appears that as Bald Eagle numbers have recovered in Manitoba, their range has expanded into what are likely suboptimal habitats compared to boreal forest sites. Some birds have learned to nest in fairly close proximity to human activity, such as boating or farming, or in cottage areas. ${ }^{3,6}$ It is not unusual to see nests located close to farms; indeed, several of the nests located along Lake Winnipegosis during the 1980 s aerial surveys were near farms (W. Koonz, pers. comm.). It is also likely that changes in agricultural practices aided in this range expansion, by increasing the food supply. Large poultry and hog farms flourished in the 1980s and 1990s, and offal produced by these operations was sometimes scavenged by Bald Eagles. Increased White-tailed Deer numbers in combination with increased vehicle traffic resulted in more roadkill, which may also have provided additional scavenging opportunities for eagles. In addition, maturation of trees across the Prairies likely provided an increased choice of nest trees.

From the numerous responses to my request for sightings and years of nest locations in "agricultural" southern Manitoba, the earliest appears to be a nest found by P. Taylor on 1 May 1993, not far from the mouth of the Red River. Other nests known to have been used in the 1990s were at a few locations along the lower Whitemouth River, near Old Pinawa, at Delta Marsh, and possibly just south of Riding Mountain National Park, plus the aforementioned Oak Hammock Marsh 
nest. All other nests were established in the $21^{\text {st }}$ century (Fig. 1).

Figure 1 shows that the few nests found in the 1990s were all located near the edge of continuous forest, with the exception of those at Delta Marsh and Oak Hammock Marsh. The latter nests were occupied at the end of the 1990s, but probably not earlier. In the first few years of the $21^{\text {st }}$ century, some nests were constructed deeper into the agricultural south; these include nests in the Killarney area, at La Broquerie, St. Jean-Baptiste, and Winnipeg. At the same time, more pairs started breeding along the Whitemouth River.

Figure 1 also shows that most nests are located along major rivers or near large lakes: The Winnipeg River/Whitemouth River system, the Red River, the south shore of Lake Manitoba, and the chain of lakes in the Pembina River Valley. Currently there appear to be only two large areas in the agricultural south of the province that are not occupied: a roughly pie-shaped region bounded by the Assiniboine, Red, and Pembina Rivers, plus the extreme southwest of the province. The first region consists primarily of vast agricultural expanses, with virtually no water bodies of any size and few woodlands, and is unlikely to support eagles. The latter area boasts some sizeable lakes, such as Oak Lake and Whitewater Lake, plus larger streams such as the tree-lined Assiniboine and Souris Rivers, which may well attract Bald Eagles in the near future. The above water bodies contain fish populations large enough to support a number of breeding Bald Eagle pairs.

In northern Manitoba, a concurrent range expansion has taken place. Although much of the northern third of the province is rather inaccessible, and hence little birded, the avifauna of the Churchill region has been extensively studied for many decades. During the 1960s, the Bald Eagle was considered a casual species in the area, with no evidence of nesting, although it may have done so in historic times. ${ }^{5}$ Sightings increased after the 1970s, and currently the species is noted regularly, especially along the Churchill River and at La Pérouse Bay. The highest daily count was 10 seen during a flight between La Pérouse Bay and Churchill Northern Studies Centre on 24 June 1998. ${ }^{4}$ In 2005, a pair of eagles usurped an Osprey nest along Goose Creek, about $15 \mathrm{~km}$ south of Churchill. Eagles have also nested about 20 to $30 \mathrm{~km}$ farther upstream on the Churchill River, at the mouths of the Monk and Deer Rivers and Heppell Creek (B. Chartier, pers. comm.). In the Hudson Bay Lowlands of Ontario, Bald Eagle sightings have also increased considerably since the 1980s, although nesting had not been confirmed as of $2005 .^{2}$ The limiting factor to expansion in the north appears to be the lack of suitable nest trees beyond the tree line.

\section{Acknowledgements}

Many thanks are due to all the correspondents who provided information about nests: Dean Berezanski, Luc Blanchette, Carrie and Helen Braden, Bonnie Chartier, Rhonda and Robin Chestnut, Cal Cuthbert, David Dawson, Grant Delaney, Ken De Smet, Scott Drieschman, Ron Dueck, Jim Duncan, Adolf Ens, Dennis Fast, Cliff Findlay, Lyle Franck, George and Phyllis Gillespie, Gord Grieef, Arno and Wally Jansen, Adam and Ken Kingdon, Bill Koonz, Gerald Machnee, Tracy Machonachie, Gord Ogilvie, Bob Porth, Brian Ransom, Brian Ratcliff, Susan and Terry Rebizant, Heinz Reimer, Will Rex, Eldon and Janet Schmidt, Jo Swartz, Dennis Swayze: Peter Taylor, John Thackuk, Bill Walley, Ron Wiebe, Tanis Young. Nicole Firlotte of Manitoba Conservation kindly allowed me 
access to aerial Bald Eagle nest survey maps. Peter Taylor produced the map; he also made many helpful comments on the manuscript. I am very grateful for his help.

1. BENT, A. C. 1937. Life histories of North American birds of prey, part 1. U.S. National Museum Bulletin No. 167. Smithsonian Institution, Washington, DC.

2. CADMAंN, M.D., D. A. SUTHERLAND, G. G. BECK, D. LEPAGE and A. R. COUTURIER (eds.). 2007. Atlas of the Breeding Birds of Ontario, $2001-2005$. Bird Studies Canada, Environment Canada, Ontario Field Ornithologists, Ontario Ministry of Natural Resources, and Ontario Nature. Toronto, ON.

3. GERRARD, J. M. and G. R. BORTOLOTTI. 1988. The Bald Eagle: haunts and habits of a wilderness monarch. Western Producer Prairie Books, Saskatoon, SK.
4. JEHL, J. R., Jr. 2004. Birdlife of the Churchill Region: Status, History, Biology. Trafford Publishing, Victoria, BC.

5. JEHL, J. R., Jr. and B. A. SMITH. 1970. Birds of the Churchill Region, Manitoba. Special Publication No. 1. Manitoba Museum of Man and Nature, Winnipeg, MB.

6. KOONZ, W.H. 1988. The Bald Eagle in Manitoba. Manitoba Natural Resources, Technical Report $88-1$.

7. MANITOBA AVIAN RESEARCH COMMITTEE. 2003. The Birds of Manitoba. Manitoba Naturalists Society, Winnipeg, MB.

8. THOMPSON, E. E. 1890. The Birds of Manitoba. Proceedings of the U.S. National Museum 13:457 -643 [No. 841].

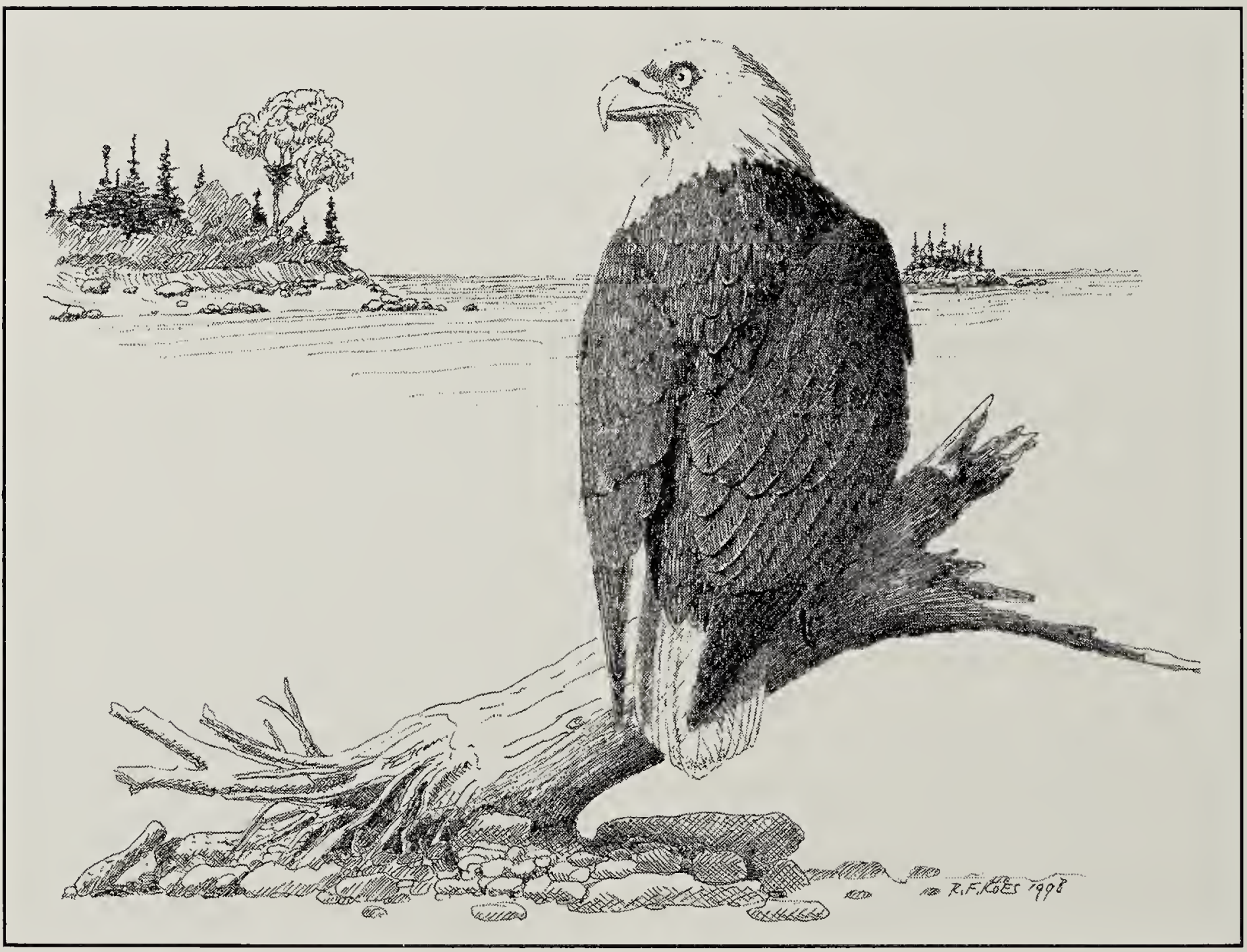

Bald Eagle.

Rudolf Koes 